SHORT COMMUNICATTION

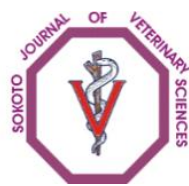

Sokoto Journal of Veterinary Sciences

(P-ISSN 1595-093X/ E-ISSN 2315-6201)

Oviawe et al/Sokoto Journal of Veterinary Sciences (2015) 13(3): 53-55

http://dx.doi.org/10.4314/sokjvs.v13i3.9

\title{
Sterilization effects on tensile strength of non-conventional suture materials as compared with nylon surgical suture
}

\author{
El Oviawe ${ }^{1 *}$, JB Adeyanju' ${ }^{2}$, T Tanimomo $^{3} \&$ ROC Kene ${ }^{1}$
}

\begin{abstract}
1. Department of Veterinary Surgery and Radiology, Faculty of Veterinary Medicine Usmanu Danfodiyo University Sokoto Nigeria

2. Department of Veterinary Surgery and Radiology, Faculty of Veterinary Medicine University of Ilorin Nigeria

3. Department of Animal Health and Production, Faculty of Veterinary Medicine, University of Abuja Nigeria
\end{abstract}

*Correspondence: Tel.: +2348062449793, E-mail: kaeteimnoh@gmail.com

\begin{abstract}
An experiment was carried out to determine the tensile strength of embroidery, braiding, cobbler's thread and nylon mono-filament fishing line (NMFL) use as non-conventional suture material. Their tensile strength were determined pre- sterilization using various calibrated weights $(50 \mathrm{gm}, 100 \mathrm{gm}, 500 \mathrm{gm})$. The non-conventional suture materials (NCS) were then subjected to different sterilization methods and tensile strength of the sterilized materials were determined using the same known weights. The procedure was repeated ten times on the NCS materials for each category and the mean tensile strength was determined for various sterilized material. The mean tensile strength of Miralene ${ }^{\circledR}$ was also determined using the above method of weight substitution. All data were analyzed using one-way analysis of variance (ANOVA) to compare mean values within the sterilization groups with 95\% confidence level (0.05). It was inferred that, mean tensile strength for cobbler's thread increased for boiling and NMFL increases for autoclave and boiling method of sterilization $(P<0.05)$. Also, mean tensile strength of NMFL and cobbler's thread was significantly superior to that of Miralene ${ }^{\circledR}$, and as such, it can be used as external suture in lieu of conventional suture materials.
\end{abstract}

Keywords: Calibrated weights, Conventional, Nylon suture material, Sterilization, Tensile Strength

Received: 04-04- 2015

Accepted: 22-10-2015

\section{Introduction}

The use of suture materials for wound closure is an ancient art where animal hair, vegetable fibers, silk, leather, and gut have all been proven to be successfully used (Parell \& Becker, 2003). A suture is a bio-material device, either natural or synthetic, used to ligate blood vessels and approximate tissues together (Pillai \& Sharma, 2010). The healing of a surgical wound involves matrix formation that bridges the margin of the wound, support cells and a regenerating vasculature, and restores the resistance of the tissues to functional stress (Wikesjo et al., 1992). The strength and adherence of the sutured tissue increase over time. The tensile strength is the maximum stress that a material can withstand while being stretched or pulled before failing or breaking (Wikipedia, 2015). Variety of absorbable and nonabsorbable materials, ranging from animal derivatives to synthetic polymers, some of which can be fabricated in braided and or monofilament form, can be use for suturing (Yaltirik et al., 2003). Choosing the appropriate suture material should be based on the appropriate tensile strength, tissue bio-compatibility, and resorption rates (Moore \& Hill, 2000). This study therefore, compares the tensile strength of non-conventional suture materials (mono-filament fishing line, cobbler's thread, embroidery and, braiding), pre and post sterilization with standard sterile surgical nylon (Miralene ${ }^{\circ}$ ) as these sutures were evaluated for their biocompatibility and reactivity on dogs (Yakubu et al., 2006). Also to determine the best sterilization method to be use on specific sewing materials as well as best suture materials to use for external surgical procedures in the absence of nylon (Miralene ${ }^{\circledR}$ ). 


\section{Materials and methods}

Commercial sewing materials which include cobblers thread (A), nylon monofilament fishing line (B), embroidery thread (C) and braiding thread (D) were used for this experiment. The tensile strength of each of the above sewing materials was determined using Hooke's law method which states that the stress imposed on a solid is directly proportional to the strain produced within the elastic limit (Anon, 2015). One meter (1m) length of the sewing material was measured and cut. The material was fixed to the cork which was fixed to the cork holder on the stand. The other end of the thread was attached to an S-shaped hook to which the weights were attached. The S-shaped hook end was attached to an aluminium container weighing $40 \mathrm{gm}$ in which several known weights (50gm, 100gm, $500 \mathrm{gm})$ were added until each sewing material breaks. The breaking point of each sewing material was recorded as the tensile strength and the experiment was repeated 10 times for each test material. The mean breaking point of each material before sterilization was determined and recorded. Eleven meter length of the materials A (embroidery thread), B (braiding), $C$ (cobblers) and D (NMFL) were rolled on heat resistant plastic material for sterilization. The suture materials designated for steam sterilization (autoclave) were labeled as; As, Bs, Cs, Ds. The above procedure was repeated for boiling water sterilization and the material was labeled as; $A b$, $\mathrm{Bb}, \mathrm{Cb}, \mathrm{Db}$. Materials for hot oven sterilization were labeled $\mathrm{Ah}, \mathrm{Bh}, \mathrm{Ch}$, Dh. Those designated for chemical sterilization (cold) was labeled as; Ac, Bc, Cc, Dc. The above procedure for determination of tensile strength pre-sterilization was repeated 10 times as well as the post sterilization and the breaking point of each of the sewing material was determined and repeated 10 times. The mean tensile strength was determined for each of the sterilized material. The mean tensile strength of the conventional suture (Miralene) was also determined using the above method of weight substitution. Values obtained for various methods of sterilization were subjected to one way Analysis of variance (ANOVA) to compare mean values within the sterilization groups using 95\% confidence level $(\mathrm{P}<0.05)$ as described by Steel \& Torrie (1980).

\section{Results and Discussion}

The mean values and standard deviation (Mean $\pm S D$ ) of breaking points for various nonconventional suture materials for Pre sterilization and post sterilization are shown in table 1 . The mean and standard deviation of presterilization value for embroidery thread was $281 \pm 12.87$. For braiding and cobblers thread the breaking points were $383 \pm 22.14$ and $9010 \pm 49.99$ respectively. That of nylon monofilament fishing line (NMFL) was $5890 \pm 8.31$.

The mean values and standard deviation (Mean \pm SD) for various sterilization methods of nonconventional suture material used for the experiment were: For embroidery threads, the values are; $302 \pm 7.89,291 \pm 22.83,278 \pm 15.49$, $257 \pm 9.49$ for various sterilization methods (hot air, cold sterilization, autoclave and boiling). The values for braiding threads are; 381 \pm 11.97 , $346 \pm 42.22$, 396 $\pm 13.50,383 \pm 14.50$. For cobblers thread and nylon mono-filament thread, the mean values are; $8890 \pm 159.51, \quad 7600 \pm 240.37$, $8290 \pm 237.81,9130 \pm 298.33$ and $5320 \pm 364.54$, $5080 \pm 91.89, \quad 8270 \pm 316.40, \quad 7290 \pm 624.41$ respectively.

The tensile strength for embroidery thread only increases when treated with hot air and cold sterilization, autoclave and boiling method had no effect on the tensile strength of the material. This is in agreement with the observation made by Yakubu et al. (2006), who observed that, tensile strength of embroidery thread was only potentiated by hot air and chemical sterilization. Braiding thread was only affected by autoclave while all other sterilization methods have no effect on its tensile strength. Cobbler's thread when passed through boiling increase its tensile strength whereas other sterilization methods have no effect. For NMFL, only autoclave and boiling increases the tensile strength of this thread materials.

Table 1: Mean \pm Standard Deviation (SD) breaking point of Non-conventional suture materials Pre and Post Sterilization in gms

\begin{tabular}{llllll}
\hline & \multicolumn{3}{c}{ Pre-Sterilization } & \multicolumn{5}{c}{$\begin{array}{c}\text { Post- } \\
\text { Sterilization }\end{array}$} \\
\cline { 2 - 6 } Materials & & $\begin{array}{l}\text { Hot Air } \\
\text { (Mean } \pm \text { SD) }\end{array}$ & $\begin{array}{l}\text { Cold Steri. } \\
\text { (Mean } \pm \text { SD) }\end{array}$ & $\begin{array}{l}\text { Autoclave } \\
\text { (Mean } \pm S D)\end{array}$ & $\begin{array}{l}\text { Boiling } \\
\text { (Mean } \pm S D)\end{array}$ \\
\hline Embroidery & $281 \pm 12.87$ & $302 \pm 7.89$ & $291 \pm 22.83$ & $278 \pm 15.49$ & $257 \pm 9.49$ \\
Braiding & $383 \pm 22.14$ & $381 \pm 11.97$ & $346 \pm 42.22$ & $396 \pm 13.50$ & $381 \pm 14.50$ \\
Cobbler & $9010 \pm 49.99$ & $8890 \pm 159.51$ & $7600 \pm 240.37$ & $8290 \pm 237.81$ & $9130 \pm 298.33$ \\
NMFL & $5890 \pm 51.95$ & $5320 \pm 364,54$ & $5080 \pm 91.89$ & $8270 \pm 316.40$ & $7290 \pm 624.41$ \\
\hline
\end{tabular}

NMFL: Nylon Monofilament Fishing Line 
From results obtained, it was inferred that $P$ values for various sterilization groups were statistically significant $(P<0.05)$. Tukey and Bonferroni's post Hoc test of multiple comparism was also performed for the groups. Various sterilization methods were compared for the groups, it was inferred that, breaking points for cobbler's thread increase for boiling and nylon monofilament fishing line (NMFL) increases for autoclave and boiling method of sterilization $(P<0.05)$, This agrees with the findings of Igna et al. (2014), who reported that steam sterilization had profound effects on each tensile strength of NMFL tested. A significant increase was observed which was proportional to the size of the material. These

\section{References}

Anonymous (2015). Hooke's Law, www.thefreedictionary.com/hooke's+law , retrieved 28-03-2015.

Banwell NM (2004). In vitro evaluation of the securos cranial cruciate ligament repair system and fluorocarbon leader line for use as lateral fabella-tibial sutures, PhD Thesis, Department of Veterinary Clinical Sciences, Faculty of the Louisiana State University and Agricultural and Mechanical College. Pp 60-62.

Igna C, Bumb D, Tascau M, Rusu L, Dascalu R, Sala $A$ \& Schuszler $L$ (2014). In vitro Mechanical Testing of NFL for the encapsular stabilization of Canine Stifle Joint. Bulletin UASVM Veterinary Medicine 71(1): 124-129.

Moore R L \& Hill M (2000). Suturing techniques for periodontal plastic surgery. Periodontology, 11(1): 103-111.

Parell GJ \& Becker GD (2003). Comparison of absorbable with nonabsorbable sutures in closure of facial skin wounds. JAMA Facial Plastic Surgery Journal, 5(6): 488490.

Pillai CK \& Sharma CP(2010). Review paper: absorbable polymeric surgical sutures: chemistry, production, properties, biodegradability, and performance. Journal of Biomaterial Application, 25(4): 291-366.

Steel RGD, \& Torrie JH, (1980), Principles and Procedures of Statistics, Second Edition, McGraw-Hill, New York. Pp 101-109. results were in contrast with the findings of Banwell (2004). From the research, it was found out that the tensile strength of both cobbler's thread and that of NMFL was greater than that of the control (Miralene ${ }^{\circledR}$ ) for various sterilization methods employed. From the study, embroidery thread can be used as external suture only after hot air or cold sterilization methods. Braiding threads can be used after steam sterilization as it increases the tensile strength of the thread. The tensile strength of MNFL and cobblers thread was significantly superior to that of Miralene ${ }^{\circledR}$, and as such, it can be used as external suture in lieu of other conventional suture materials (Miralene ${ }^{\circledR}$ ).

Sujeet Vinayak Khiste, V Ranganath, Ashish Sham Nichani (2013). Evalaution of tensile strength of surgical synthetic absorbable suture materials; an in vitro study. Journal of Periodontal and Implant Science, 43(3): 130-135.

Vasanthan A, Satheesh K, Hoopes W, Lucaci P, Williams K \& Rapley J (2009). Comparing suture strengths for clinical applications: a novel invitro study. Journal of Periodontology, 80(4): 618-624.

Wikesjo UM, Nilveus RE \& Selvig KA (1992). Significance of early healing events on periodontal repair: a review. Journal of Periodontology. 63(3): 158-165.

Wikipedia, the encyclopedia (2015). Ultimate Tensile Strength. https://en wikipedia.org/wiki

ultimate_tensile_strength, retrieved 2803-2015.

Yakubu AS, Adeyanju JB, Elsa AT \& Garba HS (2006). Evaluation of some commercial sewing materials as External sutures in Dogs. Proceedings of the $43^{\mathrm{RD}}$ Annual Congress of NVMA Minna, $6-10^{\text {th }}$ Nov.2006. Pp 60-65.

Yaltirik M, Dedeoglu K, Bilgic B, Koray M, Ersev H \& Issever $H$ (2003). Comparison of four different suture materials in soft tissues of rats. Journal of Oral Diseases. 9(6): 284286. 